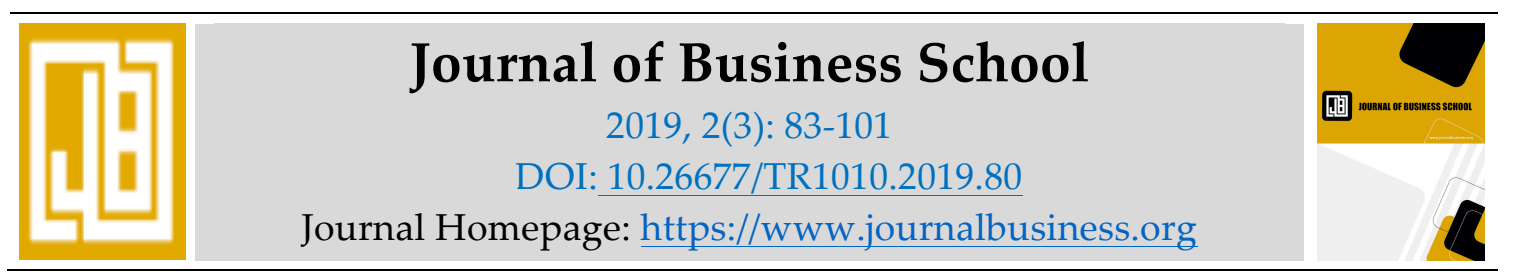

\title{
Relationship Between Exchange Rate and the Nigerian Economy
}

ANI, E.C.

Lecturers, Department of Economics, Federal University Wukari, Nigeria

OJIYA, E.A.

Lecturers, Department of Economics, Federal University Wukari, Nigeria

ABDULWAHAB, $\mathbf{S}$.

Lecturers, Department of Economics, Federal University Wukari, Nigeria

\begin{abstract}
This study examined the relationship between exchange rate and the Nigerian economy from 1986 to 2016. Secondary data obtained from the Central Bank of Nigeria statistical bulletin and the World Bank database was used. Econometric tools of analysis were employed to estimate the model. The output from the Augmented Dickey Fuller (ADF) unit root test revealed that all variables except inflation rate and interest rate were found to be stationary at first difference. The Johansen Cointegration technique reveals the presence of two and one cointegrating equations respectively indicating the existence of a long-run equilibrium relationship among Gross. The normalized cointegration equation revealed that exchange rate had positive relationship with economic growth (GDP). The slope of EXR (exchange rate) though insignificant is positive. The coefficient of INTR was observed to be negative and insignificant, while INFR was negative and statistically significant. Deriving from empirical findings, the study thus concludes that exchange rate has a positive long run relationship with economic growth. Based on the foregoing findings, the study has favoured the implementation of the following recommendations: government should encourage export promotion strategies in order to maintain a surplus balance of trade, conducive environment, adequate security, effective fiscal and monetary policies, as well as infrastructural facilities be provided so that foreign investors will be attracted to invest in Nigeria. The apex bank (Central Bank of Nigeria) should design and develop strategies that will stem the tide of rising inflation in the economy as persistent rise in prices has the tendency of adversely affecting consumers' purchasing power. Finally, monetary policy measures to reduce the present high interest rate adopted for borrowers should be initiated as fast as possible. It is only an affordable interest rate (cost of borrowing) that can motivate would-be investors to borrow and invest for the growth of the national economy.
\end{abstract}

Keywords: Exchange Rate, Economy, Nigerian 
Journal of Business School, vol.2, issue.3, pp.83-101

\section{I: INTRODUCTION}

\subsection{Background of the Study}

Foreign exchange is the means of payment for international transaction. It is made up of convertible currencies that are generally accepted for the settlement of international trade and other external obligation. Just like every other commodity, a market is established which works more like any other market having a supply curve, a demand curve and an equilibrium price and quantity. There are also conditions which are held constant (ceteris paribus). When these conditions changes, the curve shift and there is a change in the equilibrium price quantity. This market for currencies is known as the foreign exchange market.

The foreign exchange market according to the Central Bank of Nigeria is the medium of interaction between the sellers and buyers of foreign exchange. The seller of foreign exchange constitutes the supply while the buyers of foreign exchange constitute its demand. The supply of foreign exchange is derived from oil exports, non-oil export, expenditure of foreign tourist in Nigeria, capital repatriation by Nigerians resident abroad etc. Exchange rate is an important economy metric as it reflects underlying strength and competitiveness with world economies (Asinya and Takon, 2014; Akonji, 2013). Whether fixed or floating, exchange rate affects macroeconomic variables such as import, export, output, interest rate, inflation rate etc. Chong and Tan (2008) empirical analysis revealed that exchange rate is responsible for changes in macroeconomic fundamentals for the developing economies.

Mehdi (2014) stated that the effect of exchange rate fluctuations on economic growth varies in different countries, asserting that one of the factors determining the way exchange rate fluctuations affect economic growth is the development level of each country's financial markets revealing that new theories emphasize the high correlation between economic growth and innovation. Exchange rate fluctuations influence domestic prices through their effects on aggregate supply and demand. In general, when a currency depreciates it will result in higher import prices if the country is an international price taker, while lower import prices result from appreciation. The potentially higher cost of imported inputs associated with an exchange rate depreciation increases marginal costs and leads to higher price of domestically produced goods (Kandil, 2004). However, the extent of such price adjustment depends on a variety of factors such as market structure, the relative number of domestic and foreign firms in the market, the nature of government exchange rate policy and product substitutability (Fouquin, 2001).

In the bid to achieve macroeconomic stability, Nigeria's monetary authorities have adopted various exchange rate arrangements over the years. It shifted from a fixed regime in the 1960s to a pegged arrangement between the 1970s and the mid-1980s, and finally, to the various types of the floating regime since 1986 (Eze and Okpala, 2014; Dada and Oyeranti, 2012), following the adoption of the Structural Adjustment Programme (SAP). The fixed exchange rate regime induced an overvaluation of the naira and was supported by exchange control regulations that engendered significant distortions in the economy. That gave vent to massive importation of finished goods with the adverse consequences for domestic production, balance of payments position and the nation's external reserves level (Akonji, 2013). Moreover, the period was bedeviled by sharp practices perpetrated by dealers and end-users of foreign exchange (Adelowokan, 2012). These and many other problems informed the adoption of a more flexible exchange rate regime in the context of the SAP, adopted in 1986. A regime of managed float has been the predominant characteristic of the floating regime in Nigeria since 1986. Although the Naira exchange rate has witnessed some period of relative stability since the implementation of the Structural Adjustment Programme (SAP) in 1986, its continued depreciation, however, mars the economic performance of the country. The challenge of the combined effect of hikes in oil 
prices and exchange rate instabilities on macroeconomic economic stability and economic growth for oil producing nations like Nigeria is really enormous.

\subsection{Problem Statement, Objectives / Research Questions}

In recent times, the Nigerian economy has been experiencing concurrent and unstable volatility in inflation rate as well as exchange rates. Ojo and Alege (2014) have argued that the current high variability of exchange rate fluctuations in Nigeria may generate adverse effects in the form of higher price inflation and larger output contraction. The theoretical assertion came through in Nigeria in the recent times with Nigeria witnessing incessant fall in the value of Naira to US dollar which is followed by high and persistent rise in general prices of commodities.

Since September 1986, when the market determined exchange rate system was introduced via the second tier foreign exchange market, the naira exchange rate has exhibited the features of continuous depreciation and instability. This instability and continued depreciation of the naira in the foreign exchange market has resulted in declines in the standard of living of the populace, increased cost of production which also leads to cost push inflation. It has also tended to undermine the international competitiveness of non-oil exports and make planning and projections difficult at both micro and macro levels of the economy. A good number of small and medium scale enterprises have been strangulated as a result of low Dollar-Naira exchange rate and so many other problems resulting from fluctuations in exchange rates can also be identified. This movement of the exchange rate along the path of depreciation since 1986 has raised a lot of questions on the impact of exchange rate policies on the Nigerian economy, hence this study seeks to examine the relationship between exchange rate and economic growth in Nigeria. The specific objectives of the study however includes among others, to determine if exchange rate contributes significantly to Nigeria's economic growth and to examine the impact of interest rate on gross domestic product (economic growth) in Nigeria. Deriving from the objectives, the following research questions will elicit answers in the process of study:

(i) Does exchange rate have any significant positive relationship on the economic growth of Nigeria?

(ii) What is the contribution of exchange rate to economic growth in Nigeria?

(iii) What is the impact of interest rate on gross domestic product in Nigeria?

\subsection{Hypotheses of the study}

Based on the objectives of the study, the following hypotheses were formulated:

Ho: Exchange rate has no long-run relationship with the Nigerian economy

Ho: $\quad$ Exchange rate has no significant impact on economic growth in Nigeria

$\mathbf{H}_{1}$ Interest rate has no significant impact on Nigeria economic growth

\section{II: LITERATURE REVIEW}

\subsection{Conceptual Framework}

Exchange rate has been defined as the price of one currency in terms of another (Mordi, 2006). Exchange rate is the price at which one country exchanges its currency for other currencies. The increase or decrease of real exchange rate indicates strength and weakness of currency in relation to foreign currency and it is a standard for illustrating the competitiveness of domestic industries in the world market (Razazadehkarsalari, Haghiri \& Behrooznia, 2011). Azeez, Kolapo and Ajayi, (2012) noted that When there is deviation of this rate over a period of time 
from the benchmark or equilibrium, exchange rate is called exchange rate volatility. It also indicates the misalignment of exchange rate as occurred where there is multiplicity of markets parallel with the official market.

Jhingan (2010) defined exchange rate as the rate at which one currency exchanges for another Exchange rate is said to depreciates if the amount of domestic currency required for buying a foreign currency increases, while exchange rate appreciates if the amount of domestic currency required for buying a foreign currency reduces. An appreciation in the real exchange rate may create current account problems because it leads to overvaluation. Overvaluation in turn makes imports artificially cheaper while exports relatively expensive, thus reducing the international competitiveness of a country (Takaendesa, 2006). Movements in the exchange rate have ripple effects on other economic variables such as interest rate, inflation rate, unemployment, money supply; etc. These facts underscore the importance of exchange rate to the economic wellbeing of every country that opens its doors to international trade in goods and services.

Dada and Oyeranti (2012) noted that the objectives of an exchange rate policy include determining an appropriate exchange rate and ensuring its stability. Over the years, efforts have been made to achieve these objectives through the applications of various techniques and options to attain efficiency in the foreign exchange market. Exchange rate arrangements in Nigeria have transited from a fixed regime in the 1960s to a pegged regime between the 1970s and the mid-1980s and finally, to the various variants of the floating regime from 1986 with the deregulation and adoption of the structural adjustment programme (SAP). A managed floating exchange rate regime, without any strong commitment to defending any particular parity, has been the most predominant of the floating system in Nigeria since the SAP era (Obadan, 2008). Following the failures of the variants of the flexible exchange rate mechanism (the AFEM introduced in 1995 and the IFEM in 1999) to ensure exchange rate stability, the Dutch Auction System (DAS) was re-introduced on July 22, 2002. The DAS was to serve the triple purposes of reducing the parallel market premium, conserve the dwindling external reserves and achieve a realistic exchange rate for the naira. The DAS helped to stabilize the naira exchange rate, reduce the widening premium, conserve external reserves, and minimize speculative tendencies of authorized dealers. According to Chowdhury (1999), the role of exchange rate and its effects on macroeconomic performance has continued to generate interest among economists. Many economists argue that exchange rate stability facilitates production activities and economic growth. They are also of the view that misalignment in real exchange rate could distort production activities and consequently hinders exports growth and generate macroeconomic instability.

\subsection{Effect of Exchange Rate on the Growth of Nigeria's Economy}

According to Danjuma (2013), the following have been adduced as the effect of exchange rate on economic growth of many developing nations.

(a) Increase in foreign exchange earnings: The foreign exchange reserve of a country is responsive to its exchange rate which has a multiplier effect on the economic growth of a country. When there is more export due to increase in value of a country's currency, this would increase the foreign exchange reserve of the country at the Central Bank. There is a possibility of the increase in export enhancing economic growth of the country. However, in Nigeria, the foreign exchange reserve has not translated to enhanced economic growth due to low exports and more imports. 
(b) Improvement in Technology: There is empirical evidence that most of the countries having high external reserves are countries with advanced technology. The increase in currency reserves would lead to advanced countries investing their capital in Nigeria.

(c) Appreciation of National Currency: Increase in foreign exchange according to Doyle, (2001), would strengthen the value of national currency in relation to the other currencies being traded in the foreign exchange market. This would also lead to increase in the confidence of investors to trade in the national currency. However, this has not worked out for Nigeria as the naira is being weakened day in day out due to high level of corruption and capital flight ravaging the economy.

(d) Increase in the standard of living: In economies like China, Japan, USA and Switzerland with favourable external reserves, there is usually the positive effect on the people living or carrying on business in such countries. This was manifested in the Nigerian economy in the 1960s before the discovery of oil which though has resulted in higher national income but has paradoxically reduced living standards over the years.

(e) Inflation: Increase in external reserve was supposed to dampen the inflationary effect in the economy. Unfortunately, the reverse has been the case in Nigeria as more Nigerian naira is being spent on imported goods.

(f) High cost of maintenance: Foreign exchange rate management usually leads to a country procuring high debt through loans from the International Monetary Fund (IMF) or the World Bank to finance it projects. In Nigeria for example, when the naira becomes weak compared to other currencies like Dollar or Pound and there is the need to transact foreign trade with USA or any of the European countries, Nigeria would require extra cost in floating these other currencies for effective trade deals. This has also led to exposure to transaction risk, commercial risk end political risk.

\subsection{Theoretical Framework}

This study is guided by two theories viz the Purchasing Power Parity Theory and the Balance of Payment Theory. These theories are adopted due to their relevance to the study.

\subsubsection{The Purchasing Power Parity Theory:}

This Theory states that spot exchange rate between currencies will change to the differential in inflation rate between countries. The theory states that the equilibrium exchange rate between two inconvertible paper currencies is determined by the equality of their purchasing power. That is, the exchange rate between two countries is determined by their relative price levels. The purchasing power parity (PPP) theory originated from the writings of the Swedish economist Gustav (Menon \& Viswanathan, 2005). The theory states that homogeneous goods in different countries cost the same in the very same countries when measured in terms of the same currency. This implies that exchange rates between currencies are in equilibrium when their purchasing power is the same in each of the two countries. The willingness to pay a certain amount for foreign money must ultimately and essentially be due to the fact that this money possesses a purchasing power against goods and services in that country (Reid \& Joshua, 2004). Any deviation from this statement implies that a country's currency is incorrectly valued.

The theory is linked to the arbitrage hypothesis that states that if two homogeneous goods are traded at different prices in different countries, this arbitrage opportunity would be utilized, which leads to convergence of the deviations from Purchasing Power Parity towards equilibrium in the absence of arbitrage costs. There are two forms of PPP, absolute and relative. 
The absolute PPP, also known as the Law of One Price, states that a commodity costs the same regardless of what currency is used to purchase it or where it is selling (Reid \& Joshua, 2004). This theory is based on the assumptions that there are no transaction costs, no barriers to trade and the commodities being traded are homogeneous. If the trading currency is exchanged at the spot exchange rate, the price of a homogenous commodity should be identical across borders. The theory suggested use of price indexes to determine the exact price of a homogenous commodity between countries. The main challenge of this belief is in measuring Purchasing Power Parity constructed from price indexes given that different countries use different goods to determine their price level (Reid, 2005).

\subsubsection{The Balance of Payment Theory:}

This theory stipulates that under free exchange rates, the exchange rate of the currency of a country depends upon its balance of payment. According to (Brooks 2014), a favourable balance of payments raises the exchange rate, while an unfavourable balance of payments reduces the exchange rate. Thus the theory implies that the exchange rate is determined by the demand for and supply of foreign exchange.

\subsection{Empirical Review}

Adeniran, Yusuf and Adeyemi (2014) examined the impact of exchange rate on Nigeria economic growth from 1986 to 2013 using correlation and Ordinary Least Squares regression analysis to analyze the data. The result revealed that exchange rate had positive but insignificant impact on Nigeria economic growth. It was recommended that government should encourage the export promotion strategies in order to maintain a surplus balance of trade and also conducive environment, adequate security, effective fiscal and monetary, as well as infrastructural facilities should be provided so that foreign investors will be attracted to invest in Nigeria.

Attah-Obeng, Enu, Osei-Gyimah and Opoku (2013) examined the relationship between GDP growth rate and exchange rate in Ghana from the period 1980 to 2012. The study employed the graphing of the scatter diagram for the two variables which are GDP growth rate and exchange rate to establish the correlation between GDP growth rate and exchange rate using the Pearson's Product Moment Correlation Coefficient (PPMC) and finally estimated the simple linear regression using OLS. It was confirmed that undervaluation (high exchange rate) stimulates economic growth in the short run. Therefore, policy makers should stabilise monetary and fiscal policies in the long run.

Oriavwote and Oyovwi (2012) investigated the determinants of the real exchange rate in Nigeria. The objective of the study was to present a dynamic model of real exchange rate determination and empirically test the implications of changes in possible determinants of the real exchange in Nigeria. With data covering 1970-2010, the parsimonious ECM result showed amongst others that the ratio of government spending to GDP, terms of trade and technological progress are not important determinants of the real effective exchange rate in Nigeria. The result showed that capital flow, price level and nominal effective exchange rate are important determinants of the real effective exchange rate in Nigeria and recommended that the Dutch Disease syndrome holds in Nigeria and recommended amongst others that policies have to be put in place to stabilize the problem of inflation.

Mori, Asid, Lily, Mulok and Loganathan (2012) investigated the effects of exchange rate on economic growth in Malaysia using time series data spanning 1971 to 2009. The results of ARDL bounds test suggested that long-run cointegration existed between both nominal and real exchange rates and economic growth with a significant positive coefficient recorded for real 
exchange rate and concluded that both exchange rates have a similar causal effect towards economic growth and suggested that a systematic exchange rate via monetary policy be properly developed to promote the stability and sustainability of economic growth in Malaysia.

Furthermore, Using the Vector Error Correction Model (VECM) Akinlo and Lawal (2012) examined the impact of exchange rate on industrial production in Nigeria over the period 19862010. The findings confirmed the existence of long run relationship between industrial production index and exchange rate, money supply and inflation rate. Moreover, exchange rate depreciation had no perceptible impact on industrial production in the short run but had positive impact in the long run. Output, inflation and exchange rate in Nigeria was the focus of the work by Odusola and Akinola (2001). Employing a structural VAR model, evidence from the estimations demonstrated the existence of mixed results on the impact of exchange rate depreciation on output. Inflation was found to generate substantial destabilizing impact on output, suggesting that monetary authorities should play a critical role in providing enabling environment for growth. The authors concluded that prices, parallel exchange rate and lending rate were important sources of fluctuations in the official foreign exchange rate. In conclusion, most of the econometric analyses indicated that devaluations (either increases in the level of the real exchange rate or in the rate of depreciation) were associated with a reduction in output and increase in inflation.

Rasaq (2012) analysed the impact of exchange rate volatility on Macroeconomic variables. employing Correlation Matrix, Ordinary Least Square (OLS) and Granger Causality test, The findings showed that exchange rate volatility had a positive influence on Gross Domestic Product and suggested that there is need for Nigeria to improve their revenue base in term of increasing number of items meant for export, reduce over reliance on petroleum sector, reduce the importation of non essential items and increased domestic production will reduce the problem caused by exchange rate volatility.

On the effect of exchange rate on the economic sector output, Ehinomen and Oladipo (2012) examined the impact of exchange rate management on the growth of the manufacturing sector in Nigeria. Ordinary Least Square (OLS) multiple regression analysis was employed to analyse the time-series data which spanned 1986 to 2010. The empirical result of the study showed that depreciation which forms part of the structural adjustment policy (SAP) 1986, and which dominated the period under review has no significant relationship with the manufacturing sector productivity. It was found that in Nigeria, exchange rate appreciation has a significant relationship with domestic output and recommended that government should direct its exchange rate management policy towards exchange rate appreciation in order to reduce the cost of production in the manufacturing sector that depends heavily on foreign inputs while there should be total ban of importation on consumer and intermediate goods that can be produced locally.

\section{III: STUDY METHODOLOGY}

\subsection{Variables used in the Model}

The models used in this study are estimated using annual Nigeria data on some macroeconomic indicators, which includes: Gross Domestic Product (GDP); Exchange Rate (EXR); Interest Rate (INTR) and Inflation Rate (INFR) for the period 1986 - 2016. The correlation and multiple regression analysis of the ordinary least square (OLS) is the estimation technique that is being employed in this study to determine the relationship between Exchange Rate and economic growth in Nigeria.. 


\subsection{Method and Sources of Data Collection}

The study employs secondary annual time series data covering the period $1986-2016$. This period is chosen as it corresponds to the period when the Nigerian economy was deregulated and exchange rate was liberalized during the Structural Adjustment Programme (SAP). Data for the study was obtained from Central Bank of Nigeria (CBN) statistical Bulletin and World Bank Development Indicators (WBDI).

\subsection{Method of Data Analysis}

The method of data analysis employed in this study is analytical. The analytical tool used is the Ordinary Least Square (OLS) regression technique. These econometric techniques include: unit root test, co-integration test and Error Correction modeling (ECM) respectively. The emphasis would be to note whether the variables are well behaved or not. The aim is to provide answers to research questions/objectives earlier formulated.

\subsection{Model Specification}

The model which specifies the relationship between exchange and economic growth in Nigeria is significantly influenced by exchange rate as the main variable with interest rate and rate of Inflation as supporting variables respectively.

The functional form of the model is formulated below

$\mathrm{GDP}=\mathrm{f}($ Excr, Intr, Infr)

The model is restated in an econometric form as follows

GDP $=\alpha_{0}+\alpha_{1}($ Excr $)+\alpha_{2}($ Intr $)+\alpha_{3}($ Infr $)+U_{t}$

The model is specified of its log-linear form:

$\operatorname{LnGDP}=\alpha_{0}+\alpha_{1} \operatorname{Ln}($ Excr $)+\alpha_{2} \operatorname{Ln}(\operatorname{Intr})+\alpha_{3} \operatorname{Ln}(\operatorname{Infr})+e_{t} \quad \ldots$.

Where:

$\begin{array}{lll}\text { GDP } & = & \text { Gross Domestic Product } \\ \text { Excr }= & \text { Exchange Rate } \\ \text { Intr }= & \text { Interest Rate } \\ \text { Infr }= & \text { Inflation Rate } \\ \text { Ln }= & \text { Natural Logarithm } \\ \mathrm{B}_{0}= & \text { Constant } \\ \alpha_{1}, \alpha_{2} \text { and } \alpha_{3}= & \text { Coefficients of the respective variables } \\ \mathrm{e}_{\mathrm{t}} \quad= & \text { Stochastic error term }\end{array}$

In this study, exchange rate (Excr), interest rate (Intr) and inflation rate (Infr) are considered to be explanatory (independent variables) which is used to explain Gross Domestic Product (GDP), proxy for economic growth in Nigeria. In essence, GDP is the dependent variable.

\subsection{Economic a Priori Expectation}

In consonance with economic theory, an increase in exchange rate is expected to produce a positive change in output and hence economic growth in Nigeria. However, increase in interest rate and inflation rate is expected to have negative relationships with economic growth in the Nigerian economy. Hence, from the model, the a-priori expectation may be held as follows: (exchange rate $=+$; interest rate $=-$; inflation rate $=-$ ).

Based on the a-priori expectation stated above, the signs of parameters in the model are as follows: "Exchange rate" coefficient is expected to be positive because an increase in exchange rate will lead to increase in gross domestic product (GDP) in Nigeria while, "inflation rate" and "interest rate" are expected to be negative because increases in interest rate and inflation rate is 
expected to lead to a decrease in GDP, ceteri-paribus. This is because an increase in INTR will discourage investors from accessing credit thereby limiting investment and general output growth in the economy. Similarly, persistent increase in the general prices of goods and services have the tendency to impact negatively on GDP and hence the Nigerian economy over time.

\section{IV: DATA ANALYSIS AND INTERPRETATION}

\subsection{Data Presentation}

Data used for this study were essentially sourced from the Central Bank of Nigeria (CBN) statistical bulletin and World Bank Development Indicators (WBDI). The data is presented for the variables GDP, Excr, Intr and Infr rate respectively.

Table 4.1 Data Presentation

\begin{tabular}{|c|c|c|c|c|}
\hline & GDP & EXCR & INFR & INTR \\
\hline 1986 & 23.75444 & 0.562197 & 1.743471 & 0.000000 \\
\hline 1987 & 23.90520 & 1.390296 & 2.423946 & 0.000000 \\
\hline 1988 & 23.87052 & 1.512259 & 3.998407 & 0.000000 \\
\hline 1989 & 23.91091 & 1.996703 & 3.921313 & 0.000000 \\
\hline 1990 & 24.14939 & 2.084216 & 1.996658 & 2.684318 \\
\hline 1991 & 24.03355 & 2.293493 & 2.565486 & 0.728565 \\
\hline 1992 & 24.10088 & 2.850615 & 3.797484 & 0.000000 \\
\hline 1993 & 23.48258 & 3.094011 & 4.045946 & 1.475781 \\
\hline 1994 & 23.61843 & 3.090861 & 4.043607 & 0.000000 \\
\hline 1995 & 24.07482 & 3.086270 & 4.288204 & 0.000000 \\
\hline 1996 & 24.27827 & 3.085775 & 3.376505 & 0.000000 \\
\hline 1997 & 24.30184 & 3.085849 & 2.143575 & 2.810219 \\
\hline 1998 & 24.18915 & 3.085847 & 2.302223 & 3.230103 \\
\hline 1999 & 24.30319 & 4.525457 & 1.889850 & 1.018099 \\
\hline 2000 & 24.56026 & 4.622001 & 1.936335 & 0.000000 \\
\hline 2001 & 24.51059 & 4.711611 & 2.937767 & 3.171275 \\
\hline 2002 & 24.80278 & 4.792298 & 2.555410 & 0.000000 \\
\hline 2003 & 24.93770 & 4.861535 & 2.641325 & 2.153342 \\
\hline 2004 & 25.19884 & 4.889507 & 2.707919 & 2.963681 \\
\hline 2005 & 25.44398 & 4.877289 & 2.882759 & 0.000000 \\
\hline 2006 & 25.70296 & 4.857108 & 2.108943 & 0.000000 \\
\hline 2007 & 25.83797 & 4.834758 & 1.683102 & 2.452240 \\
\hline 2008 & 26.06112 & 4.775301 & 2.449105 & 1.432816 \\
\hline 2009 & 25.85601 & 5.003287 & 2.445618 & 3.165749 \\
\hline 2010 & 26.63423 & 5.012620 & 2.618869 & 0.000000 \\
\hline 2011 & 26.74367 & 5.036054 & 2.383316 & 1.781966 \\
\hline 2012 & 26.85656 & 5.059422 & 2.502829 & 1.929070 \\
\hline 2013 & 26.96737 & 5.058226 & 2.137218 & 2.327019 \\
\hline 2014 & 27.06627 & 5.066087 & 2.086589 & 2.429765 \\
\hline 2015 & 26.89927 & 5.259787 & 2.199188 & 2.609763 \\
\hline 2016 & 26.72630 & 5.535333 & 2.753661 & 2.825852 \\
\hline
\end{tabular}

Source: CBN and World Bank Development Indicators 


\subsection{Unit Root Test}

This is the first test carried out in the cointegration analysis and is known as the precointegration test. This test tries to examine the property of the variables. It is used to check for the presence of a unit root i.e. none stationarity of the variables. It is carried out using the Augmented Dickey Fuller (ADF) test for unit root. The time series properties of the variables as evaluated are presented below:

Table 4.2.1 Time Series Properties

ADF Test Result for $\log ($ GDP)

Lag Length: 0 (Automatic - based on SIC, maxlag=7)

\begin{tabular}{lccc}
\hline \hline & t-Statistic & Prob.* \\
\hline \hline Augmented Dickey-Fuller test statistic & -5.486109 & 0.0001 \\
\hline Test critical values: & $1 \%$ level & -3.679322 & \\
& $5 \%$ level & -2.967767 & \\
& $10 \%$ level & -2.622989 & \\
\hline \hline
\end{tabular}

*MacKinnon (1996) one-sided p-values.

ADF Test Result for $\log (\mathrm{EXCR})$

Lag Length: 0 (Automatic - based on SIC, maxlag=7)

\begin{tabular}{lccc}
\hline \hline & t-Statistic & Prob. \\
\hline \hline Augmented Dickey-Fuller test statistic & -5.644484 & 0.0001 \\
\hline Test critical values: & 1\% level & -3.679322 & \\
& 5\% level & -2.967767 & \\
& $10 \%$ level & -2.622989 & \\
\hline \hline
\end{tabular}

*MacKinnon (1996) one-sided p-values.

ADF Test Result for Log(INFR)

Lag Length: 0 (Automatic - based on SIC, maxlag=7)

\begin{tabular}{lccc}
\hline \hline & t-Statistic & Prob.* \\
\hline \hline Augmented Dickey-Fuller test statistic & -2.966899 & 0.0497 \\
\hline Test critical values: & $1 \%$ level & -3.670170 & \\
& $5 \%$ level & -2.963972 & \\
& $10 \%$ level & -2.621007 & \\
\hline \hline
\end{tabular}

*MacKinnon (1996) one-sided p-values.

ADF Test Result for Log(INTR)

Lag Length: 0 (Automatic - based on SIC, maxlag=7)

\begin{tabular}{lccc}
\hline \hline & t-Statistic & Prob.* \\
\hline \hline Augmented Dickey-Fuller test statistic & -4.896880 & 0.0004 \\
\hline Test critical values: & 1\% level & -3.670170 & \\
& $5 \%$ level & -2.963972 & \\
& $10 \%$ level & -2.621007 &
\end{tabular}


*MacKinnon (1996) one-sided p-values.

Source: Author's computation from E-views 8.0

Table 1(a-d) above shows the stationarity test statistics for all the variables using ADF technique. From our results, the result shows that we cannot reject the null hypothesis of unit roots for all the variables in level form except for interest rate and inflation rate which attained stationarity under I(0) order of integration. However, GDP and Excr became stationary after applying first difference for each of the variables. From the tables presented above, evidence indicated that we can reject the null hypothesis for each variable. Base on the fact that all the variables are stationary either at $\mathrm{I}(0)$ or $\mathrm{I}(1)$, the study proceeded to testing whether or not the variables are co-integrated

\subsection{Johansen Co-integration test}

The co-integration test is used to check for long run relationship between the dependent and independent variables (Ogundipe and Amaghionyeodiwe, 2013). The co-integration test was carried out using the Johansen technique and it produced the following results:

Table 4.3: Johansen Cointegration Test

Unrestricted Cointegration Rank Test (Trace)

\begin{tabular}{ccccc}
\hline \hline $\begin{array}{c}\text { Hypothesized } \\
\text { No. of CE(s) }\end{array}$ & Eigenvalue & $\begin{array}{c}\text { Trace } \\
\text { Statistic }\end{array}$ & $\begin{array}{c}0.05 \\
\text { Critical Value }\end{array}$ & Prob.** \\
\hline \hline None * & 0.795303 & 80.31799 & 47.85613 & 0.0000 \\
At most 1 & 0.599912 & 34.31754 & 29.79707 & 0.0141 \\
At most 2 & 0.155452 & 7.751457 & 15.49471 & 0.4924 \\
At most 3 & 0.093657 & 2.851792 & 3.841466 & 0.0913 \\
\hline \hline
\end{tabular}

Trace test indicates 2 cointegrating eqn(s) at the 0.05 level

* denotes rejection of the hypothesis at the 0.05 level

**MacKinnon-Haug-Michelis (1999) p-values

Unrestricted Cointegration Rank Test (Maximum Eigenvalue)

\begin{tabular}{ccccc}
\hline \hline $\begin{array}{c}\text { Hypothesized } \\
\text { No. of CE(s) }\end{array}$ & Eigenvalue & $\begin{array}{c}\text { Max-Eigen } \\
\text { Statistic }\end{array}$ & $\begin{array}{c}0.05 \\
\text { Critical Value }\end{array}$ & Prob.** \\
\hline \hline None * & 0.795303 & 46.00045 & 27.58434 & 0.0001 \\
At most 1 & 0.599912 & 26.56608 & 21.13162 & 0.0078 \\
At most 2 & 0.155452 & 4.899666 & 14.26460 & 0.7545 \\
At most 3 & 0.093657 & 2.851792 & 3.841466 & 0.0913 \\
\hline \hline
\end{tabular}

Max-eigenvalue test indicates 2 cointegrating eqn(s) at the 0.05 level

* denotes rejection of the hypothesis at the 0.05 level

**MacKinnon-Haug-Michelis (1999) p-values

Source: Author's computation E-views

The results on the examination of the stable long run relationship between exchange rate and economic growth in Nigeria as reported above indicates that there is significant long run relationship between exchange rate and the Nigerian economy since both the trace test and the maximum Eigen value test passed the test of stability. There is at least two cointegration rank at $1 \%$ and $5 \%$ level of significance respectively. In other words, they possess the features that would cause them to converge in the long-run. Since there is at least one co-integrating vector, 
an economic interpretation of the relationship between gross domestic product and the independent variables (exchange rate, interest rate and inflation rate) can be obtained by normalizing the estimates of the unconstrained co-integrating vector.

\section{Panel 1: Normalizing the Estimates of the Unconstrained Co-integrating Vector.}

1 Cointegrating Equation(s): $\quad$ Log likelihood $\quad-1073.462$

Normalized cointegrating coefficients (standard error in parentheses)

\begin{tabular}{cccc} 
GDP & EXCR & INFR & INTR \\
1.000000 & $2.92 \mathrm{E}+09$ & $-5.38 \mathrm{E}+09$ & $-1.03 \mathrm{E}+11$ \\
& $(1.0 \mathrm{E}+09)$ & $(3.9 \mathrm{E}+09)$ & $(1.1 \mathrm{E}+10)$ \\
\hline
\end{tabular}

Note: Standard errors are in parenthesis

Source: Author's computation from E-views 8.0

The parameters (i.e., long-run estimates) of the cointegrating vector for the long-run equation are presented in Panel 1. In terms of the signs and magnitude of the coefficients which signify the effect of exchange rate policy variables on economic growth, it was observed from the model that EXCR had positive relationship with economic growth (GDP). The slope of EXR (exchange rate) though insignificant is positive, thus confirming the a priori expectation in line with economic theory of a positive relationship between exchange rate and economic growth. The coefficient of INTR was observed to be negative and insignificant, while INFR was negative and statistically significant. To determine the relationship between exchange rate policy and economic growth of Nigeria, it was observed that, a percentage change in exchange rate brings about 2.92 percentage increase in economic growth, indicating a positive impact on the Nigerian economy. Interest Rate is negative and statistically insignificant, as a unit change in Interest Rate leads to $-1.03 \mathrm{E}+11$ percentage decrease in economic growth. In the same vein, inflation rate (INFR) coefficient appeared inversely related to economic growth, revealing that a percentage change in inflation rate, holding all other factors constant leads to $5.38 \mathrm{E}+09$ decrease in economic growth in Nigeria within the study period.

\subsection{Error Correction Mechanism}

In the short-run, deviations from the long-run relationship established in table 4.3 could occur due to shocks to any of the variables. In addition, the dynamics governing the short-run behavior of the model are different from those in the long-run. Due to this difference, the shortrun interactions and the adjustments to long-run equilibrium are important because of the policy implications. The error-correction model arises from the long-run co-integration relationship. To check for the speed of adjustment of the model from the short run to the long run equilibrium state, then, we consider the error correcting term (ECM). The greater the coefficient of the error correction term, the faster the speed of adjustment of the model from the short run to the long run. Below is an extract of the ECM from the VECM output.

Table 4.4: Error Correction Mechanism (ECM) output

\begin{tabular}{ccccc}
\hline \hline Error Correction: & $\mathrm{D}(\mathrm{LOG}(\mathrm{GDP}))$ & $\mathrm{D}(\mathrm{LOG}(\mathrm{EXCR}))$ & $\mathrm{D}(\mathrm{LOG}(\mathrm{INTR}))$ & $\mathrm{D}(\mathrm{LOG}(\mathrm{INFR}))$ \\
\hline \hline CointEq1 & 0.009679 & -0.073622 & 0.216369 & $-3.18 \mathrm{E}-05$ \\
& $(0.02670)$ & $\begin{array}{c}(0.01874) \\
{[-3.92858]}\end{array}$ & $\begin{array}{r}(0.13364) \\
{[1.61900]}\end{array}$ & $\begin{array}{c}(0.05501) \\
{[-0.00058]}\end{array}$ \\
\hline
\end{tabular}

Source: Author's computation using E-views 8.0 
The estimated coefficient of the ECM term which is also the speed of adjustment to equilibrium is negative as required by economic theory. Judging from the table above, the ECM coefficient 0.073622 is rightly signed and statistically significant at $5 \%$ level of significance. It was revealed that about $7 \%$ of the disequilibrium or distortion in the Nigerian economy is yearly being corrected for. Theoretically speaking, the estimated coefficient of the error correction term should be negative and lie within an interval of zero and one. Thus, the larger the magnitude of this coefficient, the faster the speed of adjustment toward the long-run equilibrium. It is instructive to note, however, that the adjustment speed of $7 \%$ is very low, and thus will act as a slow down on convergence to the equilibrium path.

The hypotheses formulated for this study are tested in line with empirical findings thus:

$\mathrm{H}_{0}$ : Exchange rate has no long-run relationship with the Nigerian economy

$\mathrm{H}_{0}: \quad$ Exchange rate has no significant impact on economic growth in Nigeria

$\mathbf{H}_{\mathbf{H}}$ : Interest rate has no significant impact on economic growth in Nigeria

To test hypothesis one above, the result from Johansen cointegration analysis is used. Judging from the cointegration outcome, a unique equilibrium longrun relationship existed between exchange rate and gross domestic product (the Nigerian economy). In line with this finding, the null hypothesis of no long run relationship between the variables in question is rejected, hence it is concluded that exchange rate has a positive long run relationship with economic growth between the study periods (1986-2016).

On hypothesis two, based on the normalized estimates of the unconstrained cointegrating vector on GDP, it was revealed that the coefficient of exchange rate though positively related to economic growth is not statistically significant in the model, thus we accept the formulated null hypothesis and conclude that exchange rate has no significant impact on economic growth in Nigeria. A similar conclusion is held for interest rate because of the low t-statistic value which revealed that interest rate is both inversely related and insignificant in explaining the model on the relationship between exchange rate and economic growth in Nigeria during the study period.

\subsection{Post-Estimation Test}

\section{(a) Autocorrelation Test}

Breusch-Godfrey Serial Correlation LM Test:

\begin{tabular}{llll}
\hline \hline F-statistic & 7.283001 & Prob. F(2,12) & 0.0085 \\
Obs*R-squared & 9.869307 & Prob. Chi-Square(2) & 0.0072 \\
\hline \hline
\end{tabular}

Source: Author's computation using E-views 8.0

From the test results presented above, the probabilities of both the F-statistic (0.0000) and the observed Rsquared (0.0001) are less than 0.05. Therefore, $H_{0}$ is not accepted, meaning autocorrelation is present.

\section{(b) Heteroscedasticity Test}

Heteroskedasticity Test: Breusch-Pagan-Godfrey 
Source: Author's computation using E-views 8.0

From the test results presented in the table above, both the probabilities of F-statistic $(0.1765)$ and the observed R-squared (0.1576) are higher than 0.05 indicating the absence of heteroscedasticity. Implying that the errors are homoscedastic and therefore useful for analysis and forecasting.

\section{(c) Normality Test}

The Jarque-Bera test result of normality is as shown below. The result revealed that the residuals of the data are normally distributed. The null hypothesis of normality of the residuals of the data is accepted at 34 per cent confidence level as indicated by the probability value of 0.64 and Jarque-Bera value of 2.160825 is greater than zero.

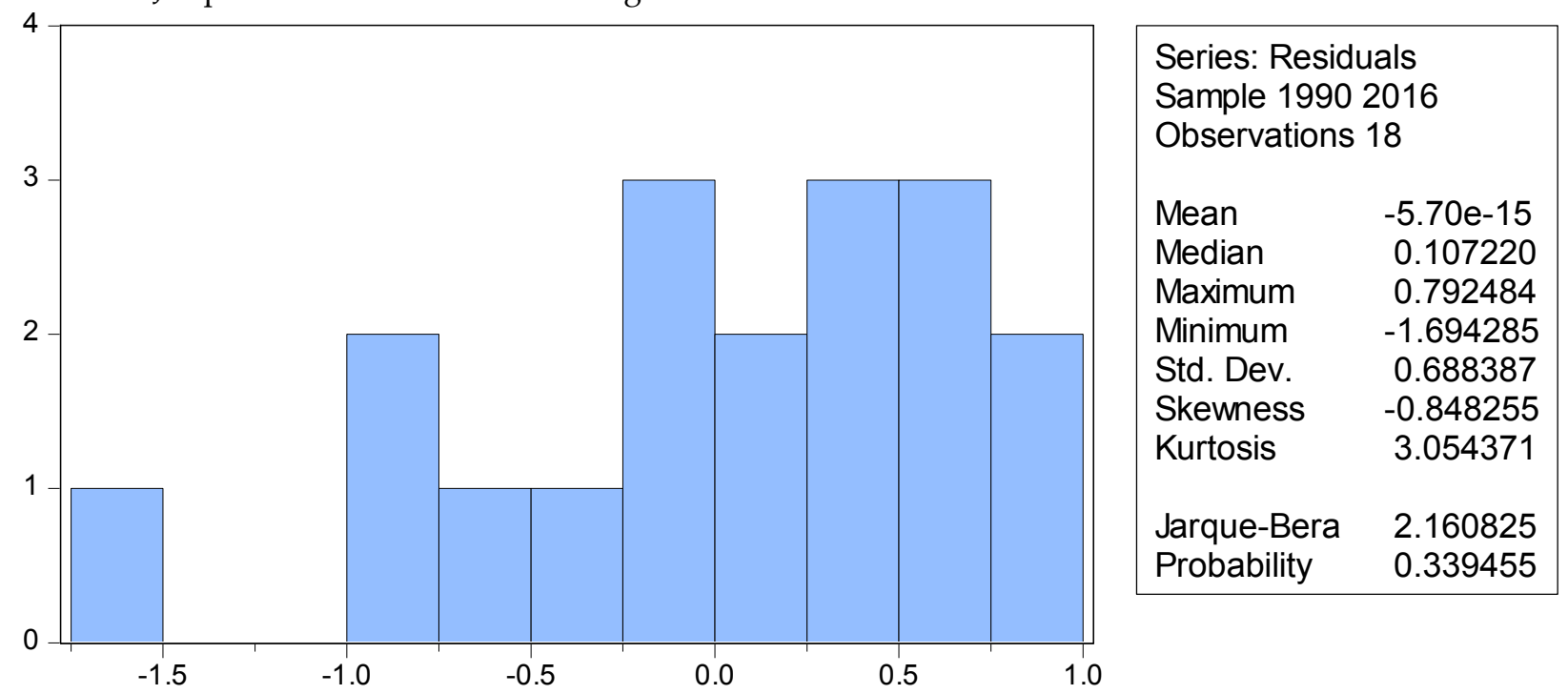

\section{V: SUMMARY, CONCLUSION AND RECOMMENDATIONS}

This study examined the relationship between exchange rate and the Nigerian economy from 1986 to 2016. Secondary data obtained from the Central Bank of Nigeria statistical bulletin and the World Bank database was used. Augmented Dickey Fuller unit root test, Johansen cointegration test and Error correction mechanism (ECM) approach to empirically test the objectives outlined in section I of the study.

The output from the Augmented Dickey Fuller (ADF) unit root test revealed that all variables except inflation rate and interest rate were found to be stationary at first difference. The Johansen Cointegration technique reveals the presence of two and one cointegrating equations respectively indicating the existence of a long-run equilibrium relationship among Gross. Evidence from shortrun analysis (Error correction mechanism) revealed that the coefficient value of -0.073622 is rightly signed and statistically significant at $5 \%$ level of significance. The coefficient indicated that about $7 \%$ of the disequilibrium or distortion in the Nigerian economy was yearly being corrected for. It is instructive to note however that the adjustment speed of $7 \%$ is very low, sluggish and unpalatable. 
Furthermore, the normalized cointegration equation revealed that exchange rate had positive relationship with economic growth (GDP). The slope of EXR (exchange rate) though insignificant is positive. The coefficient of INTR was observed to be negative and insignificant, while INFR was negative and statistically significant.

Deriving from empirical findings, the study thus concludes that exchange rate has a positive long run relationship with economic growth. Similarly, exchange rate appeared positively related to economic growth but it is statistically insignificant in the model, thus it was concluded that exchange rate has no significant impact on economic growth in Nigeria. A similar conclusion is held for interest rate because of the low t-statistic value which revealed that interest rate is both inversely related and insignificant in explaining the model on the relationship between exchange rate and economic growth in Nigeria during the study period.

Based on the findings in the foregoing paragraph, the study has favoured the implementation of the following recommendations:

Government should encourage export promotion strategies in order to maintain a surplus balance of trade, conducive environment, adequate security, effective fiscal and monetary policies, as well as infrastructural facilities be provided so that foreign investors will be attracted to invest in Nigeria.

The apex bank (Central Bank of Nigeria) should design and develop strategies that will stem the tide of rising inflation in the economy as persistent rise in prices has the tendency of adversely affecting consumers' purchasing power.

Finally, monetary policy measures to reduce the present high interest rate adopted for borrowers should be initiated as fast as possible. It is only an affordable interest rate (cost of borrowing) that can motivate would-be investors to borrow and invest for the growth of the national economy.

\section{BIBLIOGRAPHY}

Adeniran, J.O., Yusuf, S.A and Adeyemi, O. A. (2014) "The Impact of Exchange Rate Fluctuation on the Nigerian Economic Growth: An Empirical Investigation" International Journal of Academic Research in Business and Social Sciences. 4(8): 224-234

Agnes and Coeure (2001) "The survival of Intermediate Exchange Rate Regimes" Journal ofPolitical Economy, 204-566.

Ajakaiye, O. (2001), "Impact of Exchange Rate Depreciation on Sectorial Prices" NISER Monograph Series, (1986 - 2000). Ajakaiye, O. (2001), "Impact of Exchange Rate Depreciation on Sectorial Prices" NISER Monograph Series, $(1986-2000)$.

Akinmoladun, C. E. (1990) Foreign Exchange and International trade in Nigeria, Lagos, Gene Publications. 
Akpan, E. O. and Atan, J. A. (2012). Effects of exchange rate movements on economic growth in Nigeria; CBN Journal of Applied Statistics, Vol. 2, No.21.

Akpan, P. L. (2009). Foreign exchange market and economic growth in an emerging petroleum based economic. African EconomicandBusiness Review, 6(2), 46-58.

Allagky, A. G (2011) Relationship Between Effective Real Exchange Rate Volatility and Economic Growth in Togo. An Empirical Evidence. http//www.google .com

Aloku O.O. (2009). An Analysis of Interest Rate and Exchange Rate on Nigeria Economy (1975-2008). An Empirical Investigation: tittp//www.google.com.

Asher O. J (2012). The Impact of Exchange rate Fluctuation on the Nigeria Economic Growth (1980 - 2010). Unpublished B.sc Thesis of Caritas University Emene, Enugu State, Nigeria.

Azeez, B.A., Kolapo, F.T and Ajayi, L.B (2012). Effect of Exchange rate Volatility on Macroeconomic Performance in Nigeria. Interdisciplinary Journal of Contemporary Research in Business. 4(1), 149-155.

Bakare A.S (2011), - The Consequences of Foreign Exchange Rate Reforms on the Performances of Private Domestic Investment in Nigeriall International Journal of Economics And Management Sciences, Vol. 1, No. 1, Pp. 25-31

Dada, E.A and Oyeranti, O.A (2012) "Exchange Rate and Macroeconomic Aggregates in Nigeria" Journal of Economics and Sustainable development. 3(2): 93 - 101.

Danmola, R.A (2013) "The Impact of Exchange Rate Volatility on The Macro Economic Variables in Nigeria" European Scientific Journal Vol 9.pg 579

De Long J.B. (2002). Noise trader risk in financial markets. Journal of political economy 98(4), 703-738.

Dickson O. (2012), "Exchange rate volatility and economic growth in Nigeria",MediterraneanJournal of Social Sciences, 3(3), 399-407.

Dornbusch, R. (1988), Open macroeconomics, 2nd Edition, New York.

Edwards, S. and E. Levy-Yeyati (2003), "Flexible Exchange Rates as Shock Absorbers", NBER working paper 9867.

Elbadawi, Ibrahim A. \&Kaltani, Linda \& Soto, Raimundo, 2012. "Aid, Real Exchange Rate Misalignment, and Economic Growth in Sub-Saharan Africa," World Development, Elsevier, vol. 40(4), pages 681-700.

Fapeta 0. C. (2013). Foreign Exchange Management and the Nigerian Economic Growth(1960-2012). An Empirical Investigation. http//www.google.com.

Gbosi, A. N. (2005). Money, Monetary Policy and the Economy. Port Harcourt: Sodek.

Glüzmann, P. A., Levy-Yeyati, E. and F. Sturzenegger (2012) 'Exchange rate undervaluation and economic growth: Díaz Alejandro (1965) revisited', Economics Letters, vol. 117, no. 3, pp. 666-672.

Gujaranti, D. N. "Basic Econometrics 4th Edition, New-York:McGraw-Hill, 2003.

Gujarati, D. (2004), Basic Econometrics, Tata McGraw-Hill Publishing Limited New Delhi. 
Gustave C. (1918). Abnormal deviations in international exchanges. Economic journal, 28, pp 413-415.

Hausmann, R., L. Pritchett, and D. Rodrik (2005). "Growth Accelerations." Journal of Economic Growth 10 (4): 303-29.

Iulian I. and Bogdan C. (2012), Exchange Rate Regimes and Economic Growth in Central and Eastern European Countries", Procedia Economics and Finance 3 P. $18-23$

Isola, I. A., Oluwafunke, A. I., Victor, A. \&Asaleye, A. (2016). Exchange rate fluctuation and the Nigerian economic growth. EuroEconomica, 35 (2), Pp1-15.

Jimoh, S. O. (2006). "Traditional Theory of Real Exchange Rate and Options" Unpublished Thesis submitted to the Department of Banking and Finance, Enugu State Science and Technology.

Johansen, Søren (1991). "Estimation and Hypothesis Testing of Cointegration Vectors in Gaussian Vector Autoregressive Models". Econometrica. 59 (6): 1551-1580.

Johansen, S. (1992), “Testing Structural Hypotheses in A Multivariate Cointegration Analysis of the PPP and the UIP for UK", Journal of Econometrics, 53(1), 211244

Kandil, M. (2004). Exchange Rate Fluctuations and Economic Activity in Developing Countries:Theory and Evidence. Journal of Economic Development, Vol. 29. No.1

Kennedy J C (2010) The Relationship Between Exchange Rate and Economic Growth in Kenya (1970-2009).An Empirical Investigation: http// google.com.

Kretschmann, M. (2009), "Words, Deeds and Outcomes: A Survey on the Growth Effects of Exchange Regimes", Journal of Economic Surveys, 23(1), 139-164

Koutsoyianis, A. (1997), Theory of Econometrics, Second Edition.

Lawal, E.O (2016), Effect of exchange rate fluctuations on manufacturing sector output in Nigeria, Quest Journals: journal of research in business and management, 4(10): 32-39.

Levy-Yeyati, E., and Sturzenegger, F., and R. Iliana (2007), -On the Endogeneity of Exchange Rate Regimes\| (http://ideas.repec.org/p/udt/wpbsdt/veintiuno.html Retrieved on 12/11/01)

Maddala, G. S. \& Ki-In, M. O. (1992). Unit roots cointegration and structural change, Cambridge: Cambridgeb University Press.

Majekodunmi, 0. (2000), Exchange Rate Volatility: it's Impact on Nigeria Economy 1990-1998.

Marc A and Michele R (2011). The Relationship between exchange rates and international trade: A review of economic literature. Staff working paper ERSD2011-17.

McKinnon, Ronald, (1963): Optimum Currency Areas,“ American Economic Review” 53 (September): $717-725$ 
Mundel, A. Robert (1961). The Monetary Dynamics of International Adjustment Under Fixed and Flexible Exchange Rate, Quarterly Journal of Economic, 74.

Obansa, S. A. J., Okoroafor, O. K. D., Aluko, O. O., and Millicent Eze (2012). Percieved Relationship between Exchange Rate, Interest Rate and Economic Growth in Nigeria: 1970- 2010. American Journal of Humanities and Social Sciences: 1( 3), 116-124.

Obadan, M. I. (2012). "Exchange Rate Mechanism under the West African Monetary Zone "(Wamz) Mimeograph.

Ogun, O (2006). Real Exchange Rate Behaviour and Non-oil export Growth in Nigeria.African Journal of Economic Policy, 11(1), June.

Ogundipe, Adeyemi\&Amaghionyeodiwe, Lloyd, 2013. "MPRA Paper 51617, University Library of Munich, Germany.

Ojamenaye, C. (1991) "Naira Exchange Rate Policy Since 1986” Seminar Paper on The Naira Exchange Rate: Problems and Prospects, Lagos.

Olisadebe EU (1991). "Appraisal of Recent Exchange Rate Policy Measures in Nigeria",

Ojo, M.O. (1998). "Exchange Rates Developments in Nigeria: A Historical Perspective". Being Text of a paper delivered at a Seminar on "Exchange Rate Determination and Arithmetic" by Unilag Consult.

Owolabi .A.U and Adegbite .T.A (2012). Effect of exchange rate volatility on Nigerian economy. International journal of academic research in economic and management science: (November) 2013, Vol. 2, No. 6 ISSN: 2226-3624

Oyerant, O. A. (2010) Exchange Rate and Macroeconomic Aggregate in Nigeria (19702009). An Empirical Investigation: httpllwww.google.com.

Pius N. M (2012), The Relationship Between Exchange Rate and Economic Growth in Ghana (1980-2005). Empirical Investigation: httpll google.com.

Razmi A., Rapetti M. \&Skott P. (2012), “The Real Exchange Rate and Economic Development", StructuralChange and Economic Dynamics 23 (2012) 151- 169

Rodrik, D. (2008): 'The real exchange rate and economic growth', Brookings Papers on Economic Activity, vol. 39, no. 2, pp. 365-439.

Salvatore Nisticò, 2011. "Risk, Monetary Policy and the Exchange Rate," NBER Chapters,in: NBER Macroeconomics Annual 2011, Volume 26, pages 247-309 National Bureau of Economic Research, Inc.

Shehu, A. and Aliyu M. (2006). "Naira Exchange Rate and Policy Management" Unpublished Thesis submitted to the department of Economics, University of Benin.

Shehu, U.R. (2012), Impact of oil price shock and exchange rate volatility on economic growth in Nigeria: An empirical investigation, JEC, Department of the Central Bank of Nigeria, Bayero University Kano Research.

Sibanda, K. (2012). The impact of real exchange rates on economic growth: A case of South Africa, Eastern Cape: University of Fort Hare. Thesis (MCOM). 
Sozovska, A. (2004). Exchange Rate Regimes in Transition Economies: Bearing Point, USAID Fiscal Reform Project.

Tang B. (2014), "Real Exchange Rate and Economic Growth in China: A Cointegrated VAR Approach". China Economic Review, in Press, Elsevier

Tarawalie, A. B. (2010). Real exchange behaviour and economic growth: evidence from Sierra Leone. SAJEMS NS 13 (2010) NO 1, 08-23.

Tharakan, J. (1999), "Economic Growth and Exchange Rate Uncertainty", Applied Economics, 31(3), 347-358

Todaro, MP (2004). "Economic Development, Eight Low Prize Edition, New Delhi:Pearson Education".

Velasco, Andrés. 2000. "Exchange-Rate Policies for Developing Countries: What Have WeLearned? What Do We Still Not Know?" G-24 Discussion Paper no. 5. Geneva:UNCTAD.

Vieira, F.V., Holland, M., da Silva, C.G., \& Bottecchia, L.C. (2013), "Growth and Exchange Rate Volatility: A Panel Data Analysis", Applied Economics, 45(26), 3733-3741. 